\title{
«МЯГКАЯ СИЛА» В ГЛОБАЛЬНЫХ КООРДИНАТАХ ВНЕШНЕЙ ПОЛИТИКИ США
}

\begin{abstract}
Аннотация: Исследование фактора мягкой сильв во внешней политике современных наций-государств представляется в современных условиях задачей исключительно важной. Действительно, сегодня американское политическое руководство видит в качестве одной из приоритетных стратегических задач реализаиии внешней политики государства внедрение новых высокоинтеллектуальных стандартов управления, в том числе системой внешней политики. В результате в США активно формируются высокотехнологичные системы знания, которые становятся одним из основных компонентов «мягкой сильl» США, превращая её в высокоинтеллектуальную систему манипулирования сознанием собственного населения и зарубежных иелевых аудиторий в собственных - национальных - интересах. Заняв лидирующее положение в мировой информационной магистрали, США превратили внешнеполитическую пропаганду 6 важнейтее орудие, способное конструировать человеческое сознание практически влюбой точке планеть. В этом плане «мягкая сила» США, ориентированная на продвижение американских иенностей и представлений омиоустройстве, превратилась в деятельный инструмент политики, влияющий на поведение акторов международных отношений.

Review: Currently the analysis of the "soft power" factor in the foreign policy of the modern nation states becomes an extremely topical issue. Today the American political leaders consider introduction of the new high-hume administration standards to be a foreign policy priority. As a result, the US actively forms high-hume knowledge and cognition systems, which become one of the key elements of the "soft power" of the USA, making it a highly intellectual system for the manipulation of its own population and select foreign target audiences in its own national interests. The USA made foreign political propaganda an important means to construe human minds at almost any global location. In this sense the "soft power" of the USA aimed to promote the American values and world views became an actively used political instrument, influencing the actors of international relations. Ключевые слова: международные отношения, политика, США, мягкая сила, политическая нестабильность, дипломатия, интересы, иенности, безопасность, сотрудничество
\end{abstract}

Keywords: international relations, politics, the USA, soft power, political instability, diplomacy, interests, values, security, cooperation.

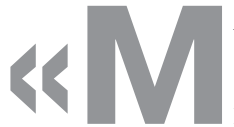

ягкая сила» - это термин, являющийся базовым для современных концепций и идеологий американского либерализма. Представители этого направления американской политической мысли утверждают, что внешняя политика должна быть направлена на сближение мировоззренческих позиций различных акторов, которое достигается экспортом либеральных ценностей. Государства, которые принимают либеральные ценности, автоматически становятся союзниками, партнерами, а затем и сателлитами лидеров либерального мира. Для достижения этой цели необходимо на время забыть о извлечении конкретной сиюминутной выгоды и направить свои усилия на реформирование политических систем и режимов будущих союзников на мировой арене по собственному образцу, в соответствии с либеральными ценностями и демократическими институтами. В этой связи можно согласиться с известным ученым Г.Ю. Филимоновым в том, что сегодня «мягкая сила» - это «сложнейшая многоуровневая система, которая позволяет США решать тактические и стратегические задачи на международной арене. Данная система воздействует на аудиторию, реализуя как национальные интересы американского государства, так и интересы глобальных элит, где доминируют представители деловых и политических кругов США» ${ }^{1}$ Вместе с тем, в возможности использования американского опыта «мягкой силы» в реализации политики (как внешней, так и вну-

\footnotetext{
${ }^{1}$ Там же.
} 
DOI: $10.7256 / 1811-9018.2013 .10 .9652$

При цитировании этой статьи сноска на dоі обязательна

\section{Право и политика $10(166) \cdot 2013$}

тренней) современной России заложен мощный модернизационный потенциал, способный придавать новый импульс ее политическому развитию в тех случаях, когда другие ресурсы истощаются или временно оказываются неэффективными. И эта точка зрения находит поддержку не только среди экспертного политологического сообщества, но и в системе государственной власти ${ }^{2}$.

Либералы также настаивают на том, что в основе современных политических конфликтов лежит несовпадение ценностей, носителями которых являются его участники. Различия в системах ценностей, участников конфликта, их порой полная несовместимость и стремление отдельных акторов навязать свои политическиеценности другимучастникам международных отношений, к тому же, преимущественно, силовым путем, порождают новую форму конфликтного взаимодействия, известную как «столкновения ценностей». Конфликты, возникающие в результате такого столкновения политических ценностей и идеологий, порожденных кардинальными различиями в мировоззренческих концепциях и доктринах различных цивилизаций (англосаксонской, романо-германской, восточноазиатской, ближневосточной и т.д.), получили название «конфликтов ценностей», основным инструментом управления которыми является «мягкая сила» .

Мягкая сила во внешней политике США является одним из основных инструментов достижения национальных интересов, который США успешно комбинируют с другими инструментами из собственного арсенала политического воздействия: жесткой силой, сторонниками использования которой выступают представители школы политического реализма, и технологиями «конструктивного» воздействия, которым предпочитают пользоваться американские конструктивисты. При этом там, где Вашингтону необходимо добиться конкретный результат в данной точке политического процесса, США используют методы политического реализма - жесткую силу, а там, где необходимо обеспечить устойчивый с течением времени результат, используется мягкая сила - основной инструмент политического либерализма.

Следы применения этого инструментария сегодня встречаются везде, где США вмешивались во внутренние дела суверенных государств - от Ирака и Афганистана до

\footnotetext{
${ }^{2}$ См. контекст использования термина «мягкая сила» в Концепции внешней политики РФ. http://www.mid.ru/brp_4.nsf/0/6D84DDEDE DBF7DA644257B160051BF7F (дата обращения:11.09.2013)

${ }^{3}$ Манойло А.В. Модели информационно-психологического управления международными конфликтами. //Вестник Моск. ун-та. Серия 12. Политические науки. - 2010. - №2 - С.85-95.
}

Европы и Латинской Америки. Типичным примером использования технологий мягкой силы во внешней политике США являются так называемые цветные революции, прокатившиеся в недавнем прошлом по странам Восточной Европы, обернувшиеся политическими кризисами и катаклизмами на пространстве СНГ, в Украине, государствах Центральной Азии, Грузии и совсем уже недавно под именем «революций арабской весны» погрузившие в «управляемый хаос» Северную Африку и Ближний Восток. Следы применения этих технологий можно найти и в современной России, изучив так называемую «революцию белых ленточек» 2011 года, и в части Союзного государства -Белоруссии, где «васильковая революция» была успешно подавлена организованными действиями власти.

Исследование роли мягкой силы во внешней политике США представляется актуальной именно в современных условиях, т.к. позволяет «сформировать интегральное видение «корневой системы» американской внешней политики в эпоху глобализации» 4 , «управляемого хаоса» и цветных революций. Это, безусловно, может быть полезно и с точки зрения обеспечения национальной безопасности России в ближнесрочной и долгосрочной перспективах, в том числе в контексте противодействия реализации на российской почве зарубежных политтехнологических проектов в формате «бархатных революций» или «Арабской весны».

Мягкая сила в политике США - это не только эффективный инструмент политического доминирования, с помощью которого США активно утверждают своеположение в системе международных отношений. Это еще и важный фактор, который определяет содержание внешней политики США на различных ее этапах и в различные временные промежутки. Особенность внешней политики США такова, что, в зависимости от того, какая управленческая команда приходит к власти, она выстраивается либо в соответствии с принципами реализма, либо в соответствии с принципами и доктринами либерализма. Так как состав политической элиты в высших эшелонах власти США довольно часто меняется, внешняя политика США испытывает бесконечные колебания от интересов к ценностям и наоборот. В результате в отношениях США с различным государствами мира многократно повторяется шаблон, характерный для отношений последних десятилетий с Афганистаном или постсоветскими государствами Центральной Азии: начав выстраивать свои отношения с другими государствами в рациональном ключе, американцы, уже добившись конкретных реалистичных результатов, неожиданно бросают нача-

\footnotetext{
${ }^{4}$ Филимонов Г.Ю. Роль «мягкой силы» во внешней политике США. Автореф. Дисс....канд. полит.н. М.: ДА МИД РФ, 2013.
} 
тое ими дело и переключаются на призрачные мессианские цели строительства истинно демократического государства, экспорт ценностей, просвещение «дикарей» и т.д. Тем самым внешняя политика США, испытывающая постоянный конфликт интересов и ценностей, в стратегическом плане демонстрирует свою неустойчивость и даже, в определенном смысле, непоследовательность. В этих условиях другие страны вынуждены выстраивать отношения с США таким образом, чтобы учитывать ее объективно существующую изменчивость. Налицо проблема, которую необходимо решать, исследуя роль мягкой силы в формировании и реализации внешней политики США, тенденции и закономерности ее проявления, политические традиции, связанные с использованием мягкой силы, новейшие идеологические концепции, регламентирующие ее применение.

В последней редакции российской концепции внешней политики также появляется термин «мягкая сила», которой придается приоритетное (в современных условиях) значение. Возможно, этот факт связан с признанием российским руководством эффективности данного подхода к регулированию международных отношений, в котором инструменты мягкой силы играют роль основной движущей силы общественнополитических изменений. Вместе с тем, сущность и содержание мягкой силы в российской концепции не раскрыта, что позволяет предположить, что идет прямое заимствование смыслов у американских коллег, из сферы американской и англосаксонской внешней политики. Это не может не настораживать, поскольку известно, что слепое копирование американских шаблонов и перенос их на иную культурную почву, как правило, дает обратный результат. Вместе с тем, сложившаяся ситуация требует в ускоренном порядке уточнения, конкретизации и расширенного толкования термина «мягкая сила» в ее российском понимании.

Вместе с тем, при оценке роли фактора «мягкой силы» в системе международных отношений и во внешней политике современных государств, а также-проблем использования этого инструмента в интересах развития государства и общества, в реализации Соединенными Штатами своей внешней политики и в защите ими своих жизненно важных национальных интересов, которые у США сегодня есть практически в любой точке Земного шара, возникает немало вопросов. Один из них - непрекращающийся конфликт интересов и ценностей (реализма и либерализма, «жесткой» и «мягкой силы») в реализации Соединенными Штатами своей внешней политики, который наиболее отчетливо на современном этапе проявляется в Афганистане, Центральной Азии и в ряде других регионов мира. Кроме того, открытым остается вопрос о том, насколько фактор «мягкой силы» во внешней политике США способен вытеснить «жесткую силу», тем самым лишив «ястребов» возможности толкать США на новые военные авантюры.

\section{Библиография:}

1. Манойло А.В. Модели информационно-психологического управления международными конфликтами. //Вестник Моск. ун-та. Серия 1

2. Политические науки. - 2010. - №2. - С.85-95.

3. Филимонов Г.Ю. Роль «мягкой силы» во внешней политике США. Автореф. Дисс....канд. полит.н. М.: ДА МИД РФ, 2013.

4. Байректаревич A.. Future of Europe (of Lisbon and generational interval) // NB: Международные отношения. - 2013. - 4. - C. 16-26. URL: http://www.enotabene.ru/wi/article_9399.html

5. Манойло А.В. Ценностные основы управления межцивилизационными конфликтами: российская модель // NB: Международные отношения.-2012.1.-C. 32-43. DOI: 10.7256/2306-4226.2012.1.279. URL: http://www.e-notabene.ru/wi/article_279.html

6. Манойло А.В. “Сирийский вопрос” Башара Асада // NB: Международные отношения. - 2013. - 2. - С. 4867. URL: http://www.e-notabene.ru/wi/article_8798.html

\section{References (transliteration):}

1. Manojlo A.V. Modeli informacionno-psihologicheskogo upravlenija mezhdunarodnymi konfliktami. // Vestnik Mosk. un-ta. Serija 1

2. Politicheskie nauki. - 2010. - №2. - S.85-95.

3. Filimonov G.Ju. Rol' «mjagkoj sily» vo vneshnej politike SShA. Avtoref. Diss....kand. polit.n. M.: DA MID RF, 2013.

4. Bajrektarevich A.. Future of Europe (of Lisbon and generational interval) // NB: Mezhdunarodnye otnoshenija. - 2013. - 4. - C. 16-26. URL: http://www.e-notabene. ru/wi/article_9399.html

5. Manojlo A.V. Cennostnye osnovy upravlenija mezhcivilizacionnymi konfliktami: rossijskaja model' // NB: Mezhdunarodnye otnoshenija.-2012.-1.-C. 32-43. DOI: 10.7256/2306-4226.2012.1.279. URL: http://www.enotabene.ru/wi/article_279.html

6. Manojlo A.V. "Sirijskij vopros" Bashara Asada // NB: Mezhdunarodnye otnoshenija. - 2013. - 2. - C. 48-67. URL: http://www.e-notabene.ru/wi/article_8798.html 